\title{
Věda jako smysl života
}

Vážení čtenáři,

Český finanční a účetní časopis se hrdě pyšní přívlastkem „,vědecký“. Dovolte mi proto položit si otázku, zda lidé vůbec touží po vědě. Většina z nás pravděpodobně odpoví, že ano. Od lékařské vědy očekáváme nové léky na staré i nové nemoci, od technického výzkumu si slibujeme nové vynálezy zpř́ijemňující práci a osobní život, bádání zemědělcủ by mělo zachránit lidstvo od hladu a poznatky přírodních věd od zkázy globálního oteplování. ${ }^{1}$ Ale co lidstvo očekává od společenských věd, a od ekonomické vědy zvláště! Přiznejme si, že většina lidí od našeho výzkumu neočekává vůbec nic. Kdysi jsem se chtěl pochlubit před svými přáteli z lékařského prostředí tím, jak bude Vysoká škola ekonomická v Praze, a konkrétně naše Fakulta financí a účetnictví pořádat velký evropský kongres, ${ }^{2}$ na který se sjede více než tisíc účetních vědců z celého světa. Sklidil jsem velmi pobavený úsměv nad čím, že to vlastně chce tolik účetních bádat. Podle prèedstav mnoha osob, a naneštěstí většina $\mathrm{z}$ nich jsou politici, bylo již v ekonomické vědě všechno již dávno objeveno. Podobným předsudkům však musely v minulosti čelit i ostatní vědecké obory.

Prohlášení o tom, že „,všechno, co kdy mohlo být vynalezeno, už bylo vynalezeno“، ${ }^{3}$ patří k nejoblíbenějším citátům na internetu. Uvedený výrok se připisuje ${ }^{4}$ Charlesi $\mathrm{H}$. Duellovi, který se ho měl dopustit v roce 1899, kdy jako ředitel Patentového úřadu USA zaslal zprávu McKinleymu, tehdejšímu prezidentovi USA. Jinými slovy mu měl vlastně navrhovat, aby zrušil jeho úřad a $v$ důsledku toho nakonec i jeho místo ředitele. Naštěstí americké archívy pečlivě schraňují veškerou oficiální korespondenci prezidentů, a badatelům ${ }^{5}$ se podařilo původní zprávu objevit. Nic tak obludného v ní však samozřejmě není, naopak C. H. Duell tvrdí, že ,náš budoucí pokrok a prosperita závisí na naší schopnosti vyrovnat se, či dokonce překonat jiné národy v rozvíjení a v pokroku ve vědě, průmyslu a obchodu“, 6 a žádá prezidenta USA o mohutnou podporu, která by měla vést k novým objevům a dalším vynálezům.

Jinému vědci se pokusili přisoudit tento výrok američtí filmaři ve filmu Cesta kolem světa za 80 dní. $^{7}$ Touto obětí se pro ně stal anglický vědec lord Kelvin of Largs, původním jménem William Thomson. Ve filmu představuje hlavního záporňáka nepřejícího pokroku, avšak ve skutečnosti to byl vážený vědec, jenž sepsal přes šest set vědeckých publikací a podal na 70 patentů. Jako fyzik se zabýval napřr. vedením tepla, a později na věčnou pamět' byla podle něho nazvána jednotka tepla Kelvin. Jeho největším úspěchem se staly jeho zásluhy o položení transantlantického telegrafního kabelu, které mu přinesly ve 42 letech šlechtický titul. Oproti

1 Z důvodu vědecké korektnosti nutno poznamenat, že ne všichni slovutní vědci se shodují v názoru na nebezpečí vyplývající z globálního oteplování.

2 27. výroční kongres European Accounting Association hostila Vysoká škola ekonomická v Praze ve dnech 1. až 3. dubna 2004, kongresu se zúčastnilo 1200 delegátů z 50 zemí.

3 „Everything that can be invented has been invented.“

4 Viz např. Morgan, C. - Langford, M.: The Book of Facts and Fallacie. New York, St. Martin's Press, 1981, nebo Cerf, S. - Navasky, V.: The Expert Speak. New York, Pantheon, 1984.

Blíže viz Sass, S.: A Patently False Patent Myth. Skeptical Inquirer, 1989, roč. 13, č. 3, s. 310-313.

6 „Our future progress and prosperity depend upon our ability, to equal, if not surpass, other nations in the enlargement and advance of science, industry and commerce. "

7 Film Cesta kolem světa za 80 dní (angl. Around the World in 80 Days) zfilmoval v r. 2004 režisér Frank Coraci, lorda Kelvina ztvárnil Jim Broadbent. 
představě a „hlubokým historickým znalostem“8 amerických scénáristů veřejně prohlásil, že ,jediná věc, kterou můžeme o budoucnosti prohlásit s naprostou jistotou je to, že se bude lišit od minulosti, nebot’ všechno se nachází ve fázi evoluce a pokroku. “9

Přezíravost slavných vědců vůči vědeckým disciplínám z ostatních oborů je všeobecně známá. Snad nejlépe to dokresluje výrok zakladatele teorie nukleární fyziky, podle něhož je „veškerá věda bud' fyzika, nebo sbírání známek. "' ${ }^{10}$ Nutno ovšem přiznat, že ekonomická věda má se sbíráním známek mnohé společné prvky. Stejně jako filatelisté sbírají známky, my sbíráme data, tak jako filatelisté třídí známky podle určitých témat (námětová filatelie), my tř́díme sesbíraná data podle určitých hledisek a stejně jako filatelisté se chlubí svými sbírkami na mezinárodních výstavách, my prezentujeme naše příspěvky na vědeckých konferencích. S filatelisty máme tedy společné zapálení každý pro svého koníčka. Přesto si ovšem dovolím tvrdit, že naše práce je o něco užitečnější než pouhé sbírání známek.

Ačkoliv pro žádnou jinou vědu než pro tu naši neplatí více citovaný výrok lorda Kelvina, přesto je náš výzkum schopen objevit nové poznatky a přinést nové metody, které mohou napomoci napřr. k odstranění příčin finančních krizí. A to je ten hlavní důvod, proč považujeme vědu současně za smysl našeho života. A to je také ten důvod, proč vydáváme náš vědecký časopis.

\author{
prof. Ing. Petr Marek, CSc. \\ předseda redakční rady \\ Českého finančního a účetního časopisu \\ a řešitel výzkumného záměru \\ Rozvoj účetní a finanční teorie \\ a její aplikace v praxi z interdisciplinárního \\ hlediska
}

\footnotetext{
$8 \mathrm{Na}$ jejich omluvu je ovšem potřeba poznamenat, že se lord Kelvin několikrát vyznamenal špatnými předpověd'mi. Napřr. v roce 1896 rentgenové paprsky prohlásil nejprve za holou mystifikaci, nicméně poté co Röntgen předložil své důkazy, nakonec přiznal svojí mýlku. V roce 1902 v rozhovoru pro Newark Advocate (26. dubna, 1902) vyjádřil své přesvědčení o tom, že „,ani balóny a ani letadla nemohou být v praxi úspěšné. “ (,No balloon and no aeroplane will ever be practically successful.")

9 "One thing we may prophesy of the future for certain - it will be unlike the past. Everything is in a state of evolution and progress. " (Lord Kelvin: An address at the Annual Meeting of the Christian Evidence Society. 23. květen, 1889).

10 „All science is either physics or stamp collecting” (citováno podle Birk, J. B.: Rutherford at Manchester. London, Heywood, 1962).
} 